Egyptian Journal of Aquatic Biology \& Fisheries

Zoology Department, Faculty of Science,

Ain Shams University, Cairo, Egypt.

ISSN $1110-6131$

Vol. 24(5): 33 - 51 (2020)

www.ejabf.journals.ekb.eg

\title{
Antimicrobial agents from sea urchin (Diadema setosum) collected from the Red
} Sea, Egypt

\author{
Waleed M.M. El-Sayed ${ }^{1 *}$, Mostafa M. Elshaer ${ }^{2}$, Hassan A.H. Ibrahim ${ }^{3}$ and \\ Mohammed E.A. El-Metwaly ${ }^{4}$
}

${ }^{1}$ Microbiology Department, National Institute of Oceanography and Fisheries, Red Sea, Egypt.

${ }^{2}$ Microbiology Department, Specialized Medical Hospital, Mansoura University, Egypt.

${ }^{3}$ Microbiology Department, National Institute of Oceanography and Fisheries, Alexandria, Egypt.

${ }^{4}$ Marine Pollution Department, National Institute of Oceanography and Fisheries, Red Sea, Egypt.

*Corresponding Author: waleedmohammedniof@gmail.com

\section{ARTICLE INFO Article History: \\ Received: April 9, 2020 \\ Accepted: June 28, 2020 \\ Online: July 2020}

Keywords:

Antimicrobial activity,

Sea urchin,

Red Sea,

Marine resources.

\section{ABSTRACT}

In the present study, sea urchin; Diadema setosumwas collected from the Egyptian Red Sea coastline for investigating its antimicrobial activities. The physicochemical parameters of seawater samples were evaluated at sites where $D$. setosum was sampled. The data exhibited a little bit of variation of hydrographical measurements at the collection sites. In addition, the concentrations of dissolved nutrients in all stations were low, which revealed the oligotrophic condition of the Red Sea. The crude extract of $D$. setosum, was evaluated for antimicrobial activity against 15 pathogen isolates of bacteria, yeast, and fungi. The results showed fluctuations in antimicrobial activity values. The pathogens (Enterococcus faecalis ATCC 29219, Staphylococcus epidermidis ATCC 12228, Klebsiella pneumoniae ATCC13883, Bacillus subtilis ATCC 6633, Vibrio fluvialis, and Candida albicans ATCC10237) were not affected, while the other pathogens were clearly influenced. The positive values were recorded in the range of 9.3 to $18.0 \mathrm{~mm}$. Additionally, the minimum inhibitory concentration (MICs) obtained from the crude extract of $D$. setosum were in the range of; 25 to $50 \mu \mathrm{g} / \mathrm{mL}$ against the affected microbes. Moreover, the activity of several commercial antibiotics was examined and compared with the results of D. setosum crude extract. Grampositive bacteria showed obvious susceptibility towards most of the tested antibiotics, while Gram-negative ones showed more resistance. It was observed that the inhibition of $D$. setosum crude extract was lower than the potent commercial antibiotics in many cases. On the other side, the results of GCMS/MS analysis of the crude extract revealed the presence of several bioactive constituents. Actually, it had 18 major compounds most of them known to possess antimicrobial activities.

\section{INTRODUCTION}

Sea urchins (Echinoidea) are one of the most important entities in the marine research due to medical, nutritional and ecological importance. Sea urchins are excellent 
model organisms useful for several lines of biotechnological research. Ecologically, Echinoidea play an important role as cleaners of the ocean bottom. The regular sea Urchins easily distinguished from irregular ones by spherical to ovate calcareous test (Manchenko and Yakovlev, 2001). Echinoids have been recorded in Red Sea since the Frinch Campaign in Egypt in 1798, where numerous new records of species (Audouin, 1826). Afteraward, several investigations were conducted to the distribution of many echinoid species along the Red Sea in addition to monographs and catalogues (Elmasry et al., 2013; Zeina et al., 2016).

During the last decade, the secondary metabolites of some marine invertebrates have gaind wide attention due to their bioactive constituents especially antimicrobial properties (Casas et al., 2011; Ibrahim et al., 2020a). Among the echinoderms, D. setosum is one of the most widely distributed sea urchins, in the Indo-West Pacific Ocean, where it occurs from the Red Sea (Gulf of Suez, Gulf of Aqaba, northern and southern Red Sea) and the east coast of Africa to Japan and Australia (Lessios et al., 2001). The occurrence of D. setosum covers both tropical waters and temperate zones (Rahman et al., 2012). Previous work showed that the gonads of D. setosum also are rich in various bioactive compounds, including polyunsaturated fatty acids (PUFAs) and $\beta$ carotene (Dincer and Cakli, 2007). PUFAs consisted of eicosapentaenoic acid [(EPA, C20:5) (n-3)] and docosahexaenoic acid [(DHA C22:6) (n-3)], have a significant preventive effect on arrhythmia, cardiovascular diseases and cancer (Pulz amd Gross, 2004). Moreover, $\beta$-carotene and some xanthophylls from $D$. setosum contains strong pro-vitamin A activity, which prevents the tumor cell development (Britton et al., 2004). Recently, Lawrence (2010) observed that D. setosum contains high level of arachidonic acid. Some parts of gonads are consumed, but mostly the sea urchins are neglected resource in many countries.

Marine D. setosum is reported to produce antibacterial compounds against various pathogenic bacteria (Marimuthu et al., 2015). However, further investigations is required to examine the activities of sea urchins metabolities against various pathogenic microbes aiming to utilize this organism optimally.

Thus, the current study was suggested to collect the most common sea urchin (Diadema setosum) from different locations along the Egyptian Red Sea to estimate the antimicrobial properties of whole extract. The expected results will confirm it contains several valuable bioactive substances.

\section{MATERIALS AND METHODS}

\section{Collection of sea urchin}

Sea urchin samples were collected from sites on the southern Red Sea, Egypt during January-March 2019 (Fig. 1). The samples of sea urchin were collected by hand from the intertidal zone in the shallow depths. The fresh samples were then washed with seawater at the sampling site to remove the adhered sediments and impurities, and then put in polyethylene bags. Quick rinsing of the sea urchin with tap water was carried out in the laboratory on the same day to get rid of the remaining impurities and epiphytes. 


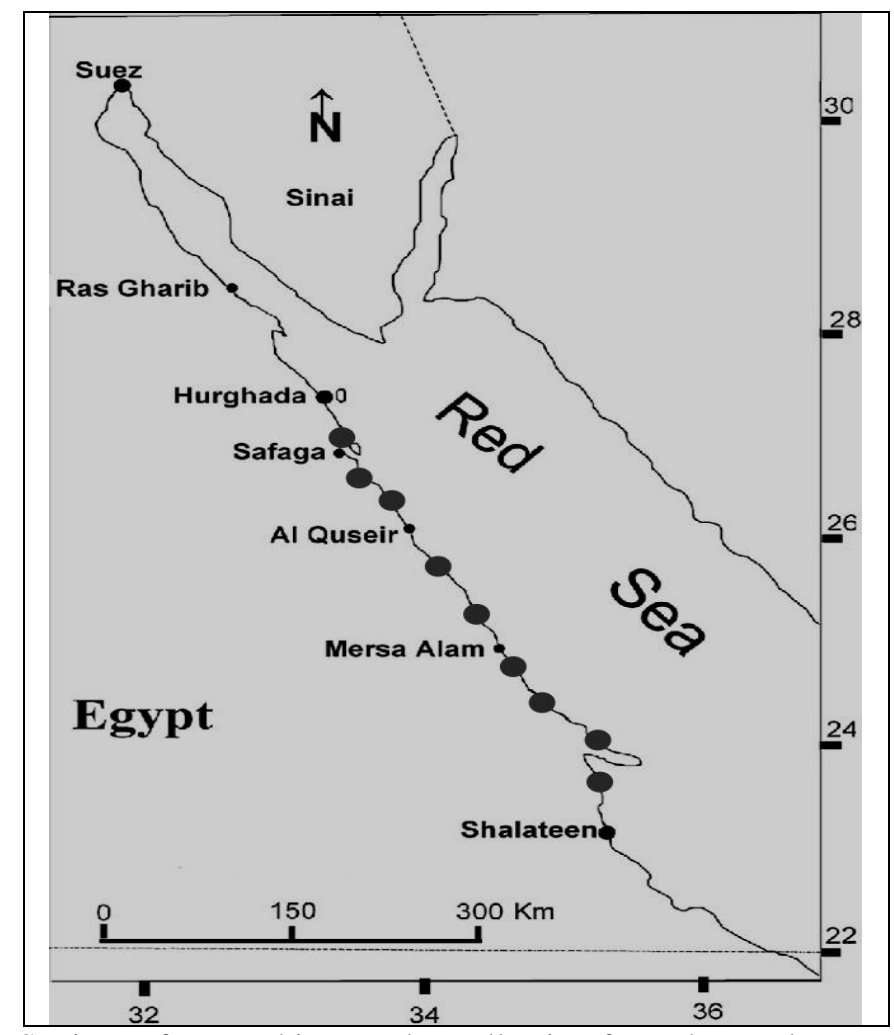

Fig. 1. Stations of sea urchin samples collection from the southern Red Sea (Hurghada to Shalateen), Egypt.

\section{Reference microorganisms and culture media}

During this work, five Gram positive bacterial pathogens (Bacillus subtilis ATCC 6633, Bacillus cereus, Staphylococcus aureus ATCC 25923, Staphylococcus epidermidis ATCC 12228, Enterococcus faecalis ATCC 29219) besides Gram negative bacterial (Pseudomonas aeruginosa ATCC 9027, Klebsiella pneumoniae ATCC 13883, Escherichia coli ATCC 8739, Aeromonas hydrophila, Vibrio fluvialis, and Vibrio damsela ATCC 33539) were used as reference strains. Also, yeast species (Candida albicans ATCC 10237) were used as reference strains. As well as, seven fungal pathogens (Rhizoctonia solani, Aspergillus niger ATCC 16404, and Fusarium solani) were also used. Some of these strains were kindly provided from Microbiology Laboratory (National Institute of Oceanography and Fisheries, Alexandria, Egypt). Some others were purchased from the Center of Fungi, Asuit University, Egypt.

Three common media were used to culture the reference strains and determine the antimicrobial activity of sea urchin crude extract include; nutrient agar (NA) (Atlas, 1997) was used for bacteria, Sabouraud dextrose agar (SDA) (Guinea et al., 2005) and potato dextrose agar (PDA) (Atlas, 1997) were used to culture yeasts and molds.

\section{Hydrographical analysis of sampling sites seawater}

Water temperature, $\mathrm{pH}$ and salinity were measured in situ at each site at the time of sampling using the Multiparameter hydrolab (Hanna Instrument; Hi 9828). For nutrient determination, subsurface water samples were collected in a liter polyethylene bottles, stored in ice box and transported to the laboratory. The samples were filtered with $0.45 \mu \mathrm{m}$ filter paper before being analyzed according to the methods described by Grassoff et al. (1999) and measured using UV/VIS spectrophotometer (JENWAY 6800). 


\section{Preparation of the crude extracts}

Sea urchin sample was mashed into very small pieces. The extraction was carried out with methanol, by soaking the material in the respective solvents $(1: 10, \mathrm{w} / \mathrm{v})$ on a rotary shaker at $150 \mathrm{rev} \min ^{1}$ at ambient temperature for $96 \mathrm{~h}$. The extract from consecutive soaking was pooled and filtered using filter paper (Whatman no 4). After evaporation of the solvent, the crude extract was re-suspended in $5 \mathrm{~mL}$ of methanol and evaporated by air to get a dry mass extract (Ibrahim et al., 2020b).

\section{Antimicrobial bioassay}

All reference strains of bacteria and yeasts were examined as pathogens. A volume of $15 \mathrm{~mL}$ of the sterilized nutrient agar for bacteria and Sabouraud dextrose agar for yeast were poured into sterile caped test tubes and were allowed to cool to $50^{\circ} \mathrm{C}$ in a water bath. About $100 \mu \mathrm{L}$ of inocula $\left(10^{8} \mathrm{CFU}\right.$ for bacteria and yeast) were added. The tubes were mixed using a vortex for 15-30 s. Thereafter, each test tube contents were poured onto a sterile $100 \mathrm{~mm}$ diameter Petri dish for solidification (Khan et al., 2019). The activity was evaluated using well-cut diffusion technique. Wells were punched out using a sterile $7 \mathrm{~cm}$ cork-borer in nutrient agar plates containing the tested microorganisms. Sea urchin crude extract was dissolved in DMSO to get a final concentration of $500 \mu \mathrm{g} / \mathrm{mL}$ as stock. About $100 \mu \mathrm{g} / \mathrm{mL}$ of crude extract was transferred into each well. They were subjected to $4^{\circ} \mathrm{C}$ incubation for $2 \mathrm{~h}$, and then were later incubated at $37^{\circ} \mathrm{C}$ for $24 \mathrm{~h}$. The results were obtained by measuring the diameter of inhibition zone three times for each well and expressed in millimeter (Ibrahim et al., 2020c).

\section{Antifungal bioassay \\ By pouring technique}

Sea urchin crude extract was tested against the indicator fungi by adding aliquots of it to PDA medium at a concentration of $10 \%(\mathrm{v} / \mathrm{v})$. One disc of the seven fungal growths was separately placed on the center of a plate containing crude extract-PDA medium. All plates were incubated at $28^{\circ} \mathrm{C}$ until the control was completely covered with fungal growth. The radius-growth of each indicator fungus was measured to estimate the suppressive effect (\%) of crude extract against the indicator fungi (Amer and Ibrahim, 2019).

\section{By well-cut diffusion technique}

One disc of the five fungal growths was separately put on the top of a plate containing PDA medium. About $100 \mu \mathrm{g} / \mathrm{mL}$ of sea urchin crude extract dissolved in DMSO was transferred into each well. All plates were incubated at $28^{\circ} \mathrm{C}$ until the control was completely covered with fungal growth. The results were obtained by measuring the inhibition zone diameter three times for each well and expressed in millimeter (Ibrahim et al., 2020a).

\section{Minimum inhibitory concentration (MIC) experiment}

The investigation of MIC was processed using microdilution method that described by Andrews (2001). The stock solution of sea urchin crude extract was diluted in DMSO to yield a final concentration of $(100 ; 75 ; 50 ; 25 ; 20 ; 15 ; 10 ; 5) \mu \mathrm{g} / \mathrm{mL}$. Then $100 \mu \mathrm{L}$ of each concentration of sample was inserted in a 96-well plate and added with $100 \mu \mathrm{L}$ suspension inoculum of test pathogen that finalized to equal with $0.5 \mathrm{McFarland}$ standards before. As controls, sterile specific broth medium for each pathogen used a sterility control and inoculum pathogens as a growth control. The MIC determination was 
performed in triplicate. MIC defined as the minimum concentration of extract that inhibited the visible growth of a pathogen after incubation. Pathogen microorganism's growth were evaluated by comparing turbidity of the sample and controls.

\section{Antibiotic sensitivity test}

Five commercial antibiotics: Cephalexin (CL, $30 \mu \mathrm{g}$ ), Rifampicin (RF, $30 \mu \mathrm{g}$ ) Piperacillin (TZP, $10 \mu \mathrm{g}$ ) Metronidazole (MTZ, $20 \mu \mathrm{g}$ ), and Amikacin (AMK, $30 \mu \mathrm{g}$ ) were chosen to test their inhibition capacity against the bacterial strains besides the yeast strain $C$. albicans. The microbial strains were inoculated in the sterilized prepared medium. Instead of the sea urchin extract, small discs of the five antibiotics were put associated with each microbial strain. All plates were subjected to $4^{\circ} \mathrm{C}$ incubation for $2 \mathrm{~h}$, and then later incubated at $37^{\circ} \mathrm{C}$ for $24 \mathrm{~h}$ (Khan et al., 2019; Shaaban et al., 2020). The results were obtained by measuring the inhibition zone diameter three times for each well and expressed in millimeter.

\section{GC-MS/MS analysis of sea urchin crude extract}

The crude sea urchin extract was prepared by soaking the fresh animal material in pure methanol $(1: 10, \mathrm{w} / \mathrm{v})$ and the filtrate was subjected to gas chromatography-mass spectrometry (GC-MS) analysis (Perkin Elmer, Waltham, MA, USA). The analyses were performed in Agilent 7693 series GC system equipped with an OV-5 capillary column (length $30 \mathrm{~m} 9$ diameter $025 \mathrm{~mm} 9$ film thickness $025 \mathrm{~mm}$; Ohio Valley Specialty Chemical, Inc., Marietta, OH, USA) and an Agilent 5975C network selective mass detector, with initial temperature $90^{\circ} \mathrm{C}$ for $1 \mathrm{~min}$, reaching to $300^{\circ} \mathrm{C}$ for $30 \mathrm{~min}$, the splitless mode with injection volume $1 \mu \mathrm{L}$ (total run time $6187 \mathrm{~min}$ ). The mass spectrometer was operated in the electron impact (El) mode at $70 \mathrm{eV}$ in the scan range $60-600 \mathrm{~m} / \mathrm{z}$. The helium was used as the carrier gas pressurized to $2223 \mathrm{psi}$, whereas the gas flow was 122 $\operatorname{mlmin}^{-1}$. The chemical constituents of the extract were identified by comparing the GCMS peaks with retention times of standards, and the mass spectra obtained were compared with those available in the Mass Spectral Library NIST 2015. The percentage of each component was estimated as the ratio of the peak area to the total chromatographic area.

\section{Statistical analysis}

The statistical software SPSS 17 was used for statistical analysis. One-way analysis of variance (ANOVA) test was performed to determine the differences between various groups. $\mathrm{P}<0.05$ was considered significant.

\section{RESULTS}

\section{Sea urchin characterization and classification}

The kind of sea urchin collected for the current study was identified morphologically as Diadema setosum (Table 1, Fig. 2). Individuals of this species arecharacterized by their long, brittle, black, movable and thorny spines (Leske, 1778). They are mostly coomon in all habitates of the Egyptian Red Sea.

\section{Hydrographical analysis of sampling sites seawater}

Some factors were estimated to draw the Hydrographical feature of seawater of which D. setosum samples were occupied. The data shown in Table 2 exhibited that the annual average of hydrographic measurements showed small variations between 
locations. Surface water temperatures ranged from $24.3^{\circ} \mathrm{C}$ in Mangrove 17 to $29.7^{\circ} \mathrm{C}$ in Qulaan.

Table 1. Classification position of collected sea urchin within Kingdom Animalia

\begin{tabular}{lc}
\hline \multicolumn{1}{c}{ Item } & Position \\
\hline Kingdom & Animalia \\
Phylum & Echinodermata \\
Class & Echinoidea \\
Order & Camarodonta \\
Family & Echinometridae \\
Genus & Diadema \\
Species & Setosum \\
Scientific name & Diadema setosum \\
\hline
\end{tabular}
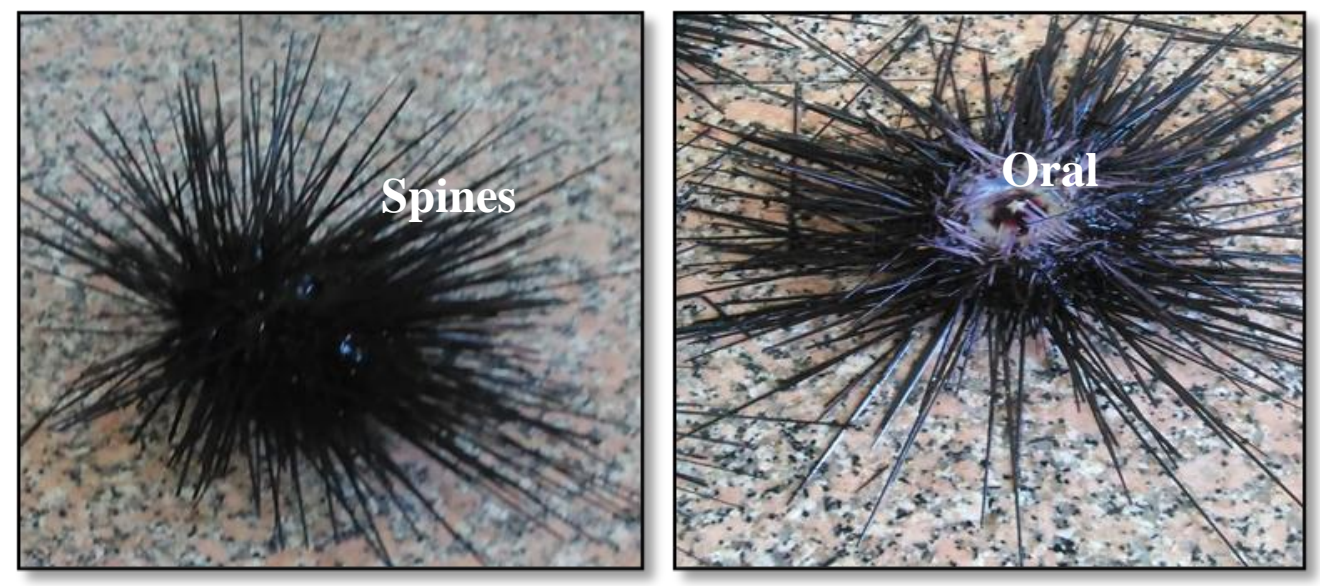

Fig. 2. Sea urchin samples collected from the Egyptian Red Sea. Individual organism showing dorsal side and spines (Left), as well as, oral and lateral side (Right).

Table 2. Hydrographical parameters and annual nutrients in different coastal water along the Red Sea.

\begin{tabular}{ccccccccc}
\hline \multirow{2}{*}{ Sampling station } & \multicolumn{3}{c}{ Physical parameter } & \multicolumn{4}{c}{ Chemical parameter } \\
\cline { 2 - 9 } & $\begin{array}{c}\text { Temp. } \\
\left({ }^{\circ} \mathbf{C}\right)\end{array}$ & $\mathbf{p H}$ & $\begin{array}{c}\text { Salinity } \\
(\mathbf{\%})\end{array}$ & $\begin{array}{c}\text { Ammonia } \\
(\boldsymbol{\mu g} / \mathbf{L})\end{array}$ & $\begin{array}{c}\text { Phosphate } \\
(\boldsymbol{\mu g} / \mathbf{L})\end{array}$ & $\begin{array}{c}\text { Silicate } \\
(\boldsymbol{\mu g} / \mathbf{L})\end{array}$ & $\begin{array}{c}\text { Nitrite } \\
(\boldsymbol{\mu g} / \mathbf{L})\end{array}$ & $\begin{array}{c}\text { Nitrate } \\
(\boldsymbol{\mu g} / \mathbf{L})\end{array}$ \\
\hline Mangrove 17 & $24.3 \pm 2.2$ & $7.93 \pm 0.1$ & $39.4 \pm 1.0$ & $21.1 \pm 6.2$ & $4.0 \pm 2.9$ & $20.2 \pm 7.3$ & $4.3 \pm 1.4$ & $15 \pm 5.2$ \\
Mangrove 43 & $26.7 \pm 0.8$ & $8.0 \pm 0.1$ & $40.1 \pm 0.3$ & $19.2 \pm 4.0$ & $1.5 \pm 1.1$ & $21.8 \pm 5.8$ & $1.3 \pm 0.8$ & $17.4 \pm 6.0$ \\
Hamraween & $28.4 \pm 0.2$ & $7.92 \pm 0.1$ & $39.9 \pm 0.1$ & $15.2 \pm 2.1$ & $5.6 \pm 5.1$ & $39.7 \pm 15.6$ & $1.3 \pm 0.4$ & $10.3 \pm 1.5$ \\
Elsharm Elbahary & $28.8 \pm 0.8$ & $7.92 \pm 0.0$ & $40.3 \pm 0.2$ & $23.8 \pm 7.3$ & $0.3 \pm 0.1$ & $25.1 \pm 3.8$ & $2.0 \pm 1.1$ & $9.9 \pm 3.1$ \\
Abu Dabab & $28.6 \pm 0.3$ & $8.05 \pm 0.1$ & $40.3 \pm 0.1$ & $27.8 \pm 4.6$ & $0.2 \pm 0.1$ & $20.9 \pm 7.2$ & $2.3 \pm 0.8$ & $25.1 \pm 8.8$ \\
Wadi El-Gemal & $28.6 \pm 0.9$ & $8.11 \pm 0.1$ & $40.1 \pm 0.3$ & $14.7 \pm 3.5$ & $2.3 \pm 0.3$ & $44.9 \pm 15.3$ & $2.0 \pm 0.7$ & $9.2 \pm 2.6$ \\
Abu Ghoson & $29.4 \pm 0.3$ & $8.5 \pm 0.3$ & $40.2 \pm 0.2$ & $17.1 \pm 2.8$ & $1.1 \pm 0.2$ & $23.2 \pm 13.8$ & $3.6 \pm 0.5$ & $14.6 \pm 2.5$ \\
Qulaan & $29.7 \pm 0.4$ & $8.1 \pm 0.14$ & $40.3 \pm 0.1$ & $21.7 \pm 3.1$ & $1.0 \pm 0.4$ & $20.2 \pm 7.2$ & $2.6 \pm 1.1$ & $9.6 \pm 4.3$ \\
Hamata & $28.5 \pm 0.5$ & $7.85 \pm 0.0$ & $41.0 \pm 0.9$ & $19.2 \pm 6.7$ & $0.3 \pm 0.2$ & $29.5 \pm 8.1$ & $1.9 \pm 1.4$ & $10.4 \pm 2.1$ \\
Wadi Lahmy & $29.1 \pm 0.3$ & $8.1 \pm 0.02$ & $39.7 \pm 0.2$ & $21.8 \pm 3.1$ & $0.4 \pm 0.1$ & $28.8 \pm 12.6$ & $2.2 \pm 1.0$ & $14.1 \pm 2.4$ \\
Shalateen & $27.7 \pm 0.7$ & $7.9 \pm 0.01$ & $40.9 \pm 0.5$ & $26.4 \pm 4.3$ & $11.4 \pm 9.0$ & $46.8 \pm 2.3$ & $2.1 \pm 0.8$ & $12.6 \pm 1.1$ \\
\hline
\end{tabular}

The $\mathrm{pH}$ ranged from 7.85 in Hamata to 8.5 in Abu Jason. Water salinity was between 39.4\% in Mangrove 17 and 41\% in Hamata. In addition, the concentrations of inorganic nutrients are illustrated in Table 2. The results indicated that the concentrations of dissolved nutrients in all stations are low, which reveal the oligotrophic condition of the Red Sea. The levels of ammonium $\mathrm{NH}_{4}-\mathrm{N}$ ranged from $14.7 \mu \mathrm{g} / \mathrm{L}$ in Wadi El-Gemal 
to $26.4 \mu \mathrm{g} / \mathrm{L}$ in Shalateen. Nitrite $\mathrm{NO}_{2}-\mathrm{N}$ reneged from $1.3 \mu \mathrm{g} / \mathrm{L}$ in Hamraween to 4.3 $\mu \mathrm{g} / \mathrm{L}$ in Mangrove 17, Nitrate $\mathrm{NO}_{3}-\mathrm{N}$ ranged from $9.2 \mu \mathrm{g} / \mathrm{L}$ in Wadi El-Gemal to 25.1 $\mu \mathrm{g} / \mathrm{L}$ in Abu Dabab. The levels of phosphate $\mathrm{PO}_{4}-\mathrm{P}$ ranged from $0.2 \mu \mathrm{g} / \mathrm{L}$ in $\mathrm{Abu}$ Dabab to $11.4 \mu \mathrm{g} / \mathrm{L}$ in Shalateen. The reactive silicate $\mathrm{SiO}_{4}$ ranged from $20.2 \mu \mathrm{g} / \mathrm{L}$ in Qulaan to $46.8 \mu \mathrm{g} / \mathrm{L}$ in the Shalateen station.

\section{Screening of antimicrobial activity of $D$. setosum crude extract}

The antimicrobial effects of the crude extracts obtained from $D$. setosum, were expressed in inhibition zone ( $\mathrm{mm}$ ). In general, six pathogens (five bacteria and one yeast) were not affected, they were; E. faecalis ATCC 29212, S. epidermidis ATCC 12228, K. pneumoniae ATCC 13883, B. subtilis 6633, V. fluvialis, and C. albicans ATCC 10237. The other pathogens were clearly influenced in low activities $(\leq 10 \mathrm{~mm})$, moderate activities $(\sim 10-14 \mathrm{~mm})$, or high activities $(\sim 15-19 \mathrm{~mm})$. In particular, the positive values were recorded in the range of 9.3 to $18.0 \mathrm{~mm}$. However, the most affected microbe by the crude extract obtained from D. setosum was Vibrio damsela ATCC 33539, followed by $S$. typhimurium that was $17.5 \mathrm{~mm}$.

Table 3. Antibacterial and antifungal activity of a crude extract expressed in the inhibition zone ( $\mathrm{mm}$ ) from different $D$. setosum collection sites.

\begin{tabular}{lc}
\hline Microbial strains & Average zone of inhibition (mm) \\
\hline E. coli ATCC 8739 & $12.0 \pm 0.5$ \\
E. faecalis ATCC 29212 & 0.0 \\
S. aureus ATCC 25923 & $14 \pm 0.1$ \\
P. aeruginosa ATCC 9027 & $16 \pm 0.1$ \\
S. epidermidis ATCC 12228 & 0.0 \\
K. pneumoniae & 0.0 \\
S. typhimurium & $17.5 \pm 0.5$ \\
B. subtilis 6633 & 0.0 \\
A. hydrophila & $12.3 \pm 0.5$ \\
$V$. fluvialis & 0.0 \\
V. damsela ATCC 33539 & $18.0 \pm 0.0$ \\
C. albicans ATCC 10237 & 0.0 \\
F. solani & $15.5 \pm 0.7$ \\
A. niger ATCC 16404 & $13.3 \pm 0.7$ \\
R. solani & $10.6 \pm 0.5$ \\
\hline Zero means no activity detected, low activity; $\leq 10$ mm, moderate activity; \\
$\sim$ 10 mm, high activity; $\sim 15$ mm, and very high activity; 20 mm.
\end{tabular}

\section{MIC evaluation of $D$. setosum crude extract}

Assay of MIC can be imply to elect the best fit concentration of various antimicrobial agents for a particular application. The MIC data obtained from the crude extract of $D$. setosum was $25 \mu \mathrm{g} / \mathrm{mL}$ against both $P$. aeruginosa ATCC 9027 and A. niger ATCC 16404, while it was detected as $50 \mu \mathrm{g} / \mathrm{mL}$ for $S$. aureus ATCC 25923, $S$. typhimurium, B. subtilis ATCC 6633, F. solani, and $R$. solani. These data are represented in Table 4.

\section{Comparing antimicrobial activity of $D$. setosum extract and commercial antibiotics}

On comparison level, the activity of several commercial antibiotics (mm) was examined and then compared to the results of D. setosum crude extract (mm) (Table 5). Basically, Gram positive showed obvious susceptibility towards most of the tested antibiotics. In fact, B. subtilis was sensitive towards Cephalexin, Rifampicin, and 
Piperacillin, while it was resistant towards both Metronidazole and Amikacin. Also, $B$. cereus, was sensitive towards Cephalexin, Rifampicin, and Amikacin, while it was resistant towards both Piperacillin and Metronidazole. As well as, S. aureus was sensitive toward both Cephalexin and Metronidazole, while it was resistant towards Rifampicin, Piperacillin, and Amikacin. On contrary, S. epidermidis ATCC 12228, E. faecalis, and K. pneumoniae ATCC 13883 exhibited clear resistance towards all tested antibiotics.

Table 4. Minimum inhibitory concentration $(\mu \mathrm{g} / \mathrm{mL})$ of $D$. setosum crude extract against microbial strains expressed in the inhibition zone $(\mathrm{mm})$.

\begin{tabular}{lcc}
\hline Microbial strain & MICs $(\boldsymbol{\mu g} / \mathbf{m l})$ & Inhibition zone $(\mathbf{m m})$ \\
\hline E. coli ATCC 8739 & 25 & $5.3 \pm 0.7$ \\
E. faecalis ATCC 29212 & ND & $0.0 \pm 0.0$ \\
S. aureus ATCC 25923 & 50 & $6.5 \pm 0.5$ \\
P. aeruginosa ATCC 9027 & 25 & $5.7 \pm 0.6$ \\
S. epidermidis ATCC 12228 & ND & $0.0 \pm 0.0$ \\
K. pneumoniae ATCC 13883 & ND & $0.0 \pm 0.0$ \\
S. typhimurium & 50 & $5.7 \pm 0.6$ \\
B. subtilis ATCC 6633 & 50 & $7.0 \pm 1.0$ \\
A. hydrophila & ND & $0.0 \pm 0.0$ \\
V. fluvialis & ND & $0.0 \pm 0.0$ \\
V. damsela ATCC33539 & ND & $0.0 \pm 0.0$ \\
C. albicans ATCC 10237 & ND & $0.0 \pm 0.0$ \\
F. solani & 50 & $4.5 \pm 0.5$ \\
A. niger ATCC 16404 & 25 & $1.7 \pm 1.5$ \\
R. solani & 50 & $4.8 \pm 0.8$ \\
\hline
\end{tabular}

The applied range of MICs was about 1, 25, 50, 125, 250, and $500 \mu \mathrm{g} / \mathrm{mL}$. ND means not detected.

Table 5. Effect of different commercial antibiotics on some bacterial strains in comparison to D. setosum extract.

\begin{tabular}{|c|c|c|c|c|c|c|}
\hline \multirow{2}{*}{$\begin{array}{c}\text { Reference } \\
\text { organism }\end{array}$} & \multirow{2}{*}{$\begin{array}{l}\text { Inhibition zone } \\
(\mathrm{mm}){ }^{*} \text { of } D . \\
\text { setosum crude } \\
\text { extract }(30 \\
\mu \mathrm{g} / \mathrm{mL})\end{array}$} & \multicolumn{5}{|c|}{ Inhibition zone (mm) /Antibiotic (disc/ $\mu \mathrm{g})$} \\
\hline & & $\begin{array}{l}\text { Cephalexin } \\
(\mathrm{CL}, \mathbf{3 0} \boldsymbol{\mu g})\end{array}$ & $\begin{array}{l}\text { Rifampicin } \\
(\mathrm{RF}, 30 \mu \mathrm{g})\end{array}$ & $\begin{array}{c}\text { Piperacill } \\
\text { in }(\mathrm{TZP}, \\
10 \mu \mathrm{g})\end{array}$ & $\begin{array}{c}\text { Metronidazole } \\
\text { (MTZ, 20 } \mu \mathrm{g})\end{array}$ & $\begin{array}{c}\text { Amikacin } \\
\text { (AMK, } 30 \\
\mu \mathrm{g})\end{array}$ \\
\hline E. coli & 12 & 23 & 0 & 0 & 0 & 0 \\
\hline E. faecalis & 0 & 6 & 6 & 6 & 6 & 0 \\
\hline S. aureus & 14 & 30 & 9 & 9 & 29 & 8 \\
\hline P. aeruginosa & 16 & 0 & 0 & 0 & 12 & 0 \\
\hline S. epidermidis & 0 & 0 & 0 & 0 & 9 & 0 \\
\hline K. pneumonia & 0 & 0 & 0 & 7 & 0 & 9 \\
\hline B. cereus & 0 & 25 & 14 & 6 & 0 & 22 \\
\hline B. subtilis & 0 & 23 & 21 & 13 & 7 & 0 \\
\hline
\end{tabular}

These values taken were represented as the highest average from Table 3.

0 ; no activity (Resistant), $\sim 10 \mathrm{~mm}$; moderate activity, $\sim 15 \mathrm{~mm}$; high activity, and $\sim 20$ mm very high activity. Susceptible/sensitive is considered when the clearance inhibition zone detected around well or disc.

Also, $P$. aeruginosa showed the same results against them except for Cephalexin and Metronidazole, where they showed intermediate sensitivity. In addition, E. coli was only susceptible against Cephalexin. However, data confirmed that the Gram negative were more resistant than Gram positive. It was observed that the inhibition of D. setosum crude extract was lower than the potent commercial antibiotics in many cases. 


\section{GM-MS/MS analysis of $D$. setosum crude extract}

The current study was extended to estimate the GC-MS spectra of Diadema setosum crude extract. The obtained results of GC-MS/MS revealed the presence of several bioactive constituents, with 18 major compounds (Fig. $3 \&$ Table 6).

Table 6. Chemical constituents detected in D. setosum crude extract by GC-MS/MS analysis

\begin{tabular}{|c|c|c|c|c|c|c|c|c|}
\hline $\begin{array}{l}\text { Peak } \\
\text { No. }\end{array}$ & Compound name & $\underset{(\min )}{\text { RT }}$ & $\begin{array}{l}\text { Molecular } \\
\text { formula }\end{array}$ & $\begin{array}{l}\text { MW } \\
(\mathbf{m} / \mathbf{z})\end{array}$ & Hit & SI & RSI & $\begin{array}{c}\text { Prob. } \\
(\%)\end{array}$ \\
\hline 1 & Dimethyl Disulfide & 5.55 & $\mathrm{C}_{2} \mathrm{H}_{6} \mathrm{~S}_{2}$ & 94 & 1 & 859 & 871 & 46.85 \\
\hline 2 & S-Methyl methanethiosulfonate & 5.95 & $\mathrm{C}_{2} \mathrm{H}_{6} \mathrm{O}_{2} \mathrm{~S}_{2}$ & 126 & 1 & 556 & 755 & 29.56 \\
\hline 3 & $\begin{array}{l}\text { 3,7,7-Trimethyl-8-(2-methyl- } \\
\text { propenyl)-bicyclo[4.2.0]oct-2-ene }\end{array}$ & 6.08 & $\mathrm{C}_{15} \mathrm{H}_{24}$ & 204 & 1 & 532 & 657 & 10.40 \\
\hline 4 & 1,2,4-Trithiolane & 6.13 & $\mathrm{C}_{2} \mathrm{H}_{4} \mathrm{~S}_{3}$ & 124 & 1 & 591 & 881 & 48.95 \\
\hline 5 & 17.alfa.,21á-28,30-Bisnorhopane & 6.23 & $\mathrm{C}_{28} \mathrm{H}_{48}$ & 384 & 2 & 563 & 577 & 6.34 \\
\hline 6 & 1,3,5,7,9-Pentathiecane & 6.61 & $\mathrm{C}_{5} \mathrm{H}_{10} \mathrm{~S}_{5}$ & 230 & 1 & 550 & 736 & 13.47 \\
\hline 7 & $\begin{array}{l}\text { 3-Isopropylidene-tricyclo } \\
{[4.3 .1 .1(2,5)] \text { undecane -10-one }}\end{array}$ & 6.77 & $\mathrm{C}_{14} \mathrm{H}_{20} \mathrm{O}$ & 204 & 1 & 629 & 701 & 9.23 \\
\hline 8 & $\begin{array}{l}\text { 4,25-Secoobscurinervan-4-one, O- } \\
\text { acetyl-22-ethyl-15,16-dimethoxy-, } \\
\text { (22à)- }\end{array}$ & 6.97 & $\mathrm{C}_{27} \mathrm{H}_{36} \mathrm{~N}_{2} \mathrm{O}_{6}$ & 484 & 4 & 561 & 580 & 12.08 \\
\hline 9 & Cyclohexasiloxane, dodecamethyl-, & 7.11 & $\mathrm{C}_{12} \mathrm{H}_{36} \mathrm{O}_{6} \mathrm{Si}_{6}$ & 444 & 1 & 757 & 842 & 91.42 \\
\hline 10 & $\begin{array}{l}\text { 2,7-Diphenyl-1,6-dioxopyridazino } \\
\text { [4,5:2',3'] pyrrolo[4',5'-d] pyridazine }\end{array}$ & 7.88 & $\mathrm{C}_{20} \mathrm{H}_{13} \mathrm{~N}_{5} \mathrm{O}_{2}$ & 355 & 1 & 573 & 609 & 23.66 \\
\hline 11 & Z, Z, Z-1,4,6,9-Nona Decatetraene & 7.95 & $\mathrm{C}_{19} \mathrm{H}_{32}$ & 260 & 1 & 553 & 657 & 5.92 \\
\hline 12 & Unidentified compound & 8.10 & $\mathrm{C}_{36} \mathrm{H}_{46} \mathrm{O}_{8}$ & 606 & 1 & 577 & 578 & 20.47 \\
\hline 13 & Galactonic phenylhydrazide & 8.23 & $\mathrm{C}_{12} \mathrm{H}_{18} \mathrm{~N}_{2} \mathrm{O}_{6}$ & 286 & 1 & 567 & 624 & 8.88 \\
\hline 14 & Cycloheptasiloxane, tetradecamethyl- & 9.12 & $\mathrm{C}_{14} \mathrm{H}_{42} \mathrm{O}_{7} \mathrm{Si}_{7}$ & 518 & 1 & 731 & 822 & 73.28 \\
\hline 15 & Cyclooctasiloxane, hexadecamethyl- & 11.08 & $\mathrm{C}_{16} \mathrm{H}_{48} \mathrm{O}_{8} \mathrm{Si}_{8}$ & 592 & 1 & 665 & 800 & 46.71 \\
\hline 16 & $\begin{array}{l}\text { 2-Methyl-3,5-dinitrobenzyl alcohol, } \\
\text { tert-butyldimethylsilyl ether }\end{array}$ & 12.11 & $\mathrm{C}_{14} \mathrm{H}_{22} \mathrm{~N}_{2} \mathrm{O}_{5} \mathrm{Si}$ & 326 & 1 & 567 & 679 & 8.26 \\
\hline 17 & $\begin{array}{l}\text { (5á) Pregnane-3,20á-diol, 14à,18à- } \\
\text { [4-methyl-3-oxo-(1-oxa-4-azabutane- } \\
\text { 1,4-diyl)]-, diacetate }\end{array}$ & 12.81 & $\mathrm{C}_{28} \mathrm{H}_{43} \mathrm{NO}_{6}$ & 489 & 1 & 654 & 787 & 48.35 \\
\hline 18 & $\begin{array}{l}\text { 5-one, 9,9a-bis(acetyloxy)- } \\
\text { 1,1a,1b,2,4a,7a,7b,8,9,9a-decahydro }\end{array}$ & 12.16 & $\mathrm{C}_{24} \mathrm{H}_{36} \mathrm{O}_{9}$ & 464 & 1 & 575 & 587 & 37.35 \\
\hline
\end{tabular}

For instance, Dimethyl Disulfide (46.85\%), which uses as a food additive and works as an effective product for operators in the petrochemicals industry. On another hands, Cyclohexasiloxane, dodecamethyl- (91.42\%)is an oily liquid. It is odorless. It is very slightly soluble in water. A dodecamethylcyclohexasiloxane used in cosmetic and personal care products, dermal exposure and inhalation toxicity study. The chemical profiles of other componds are mainly: S-Methylmethane thiosulphonate (29.56\%), 3,7,7Trimethyl-8-(2-methyl-propenyl)-bicyclo[4.2.0]oct-2-ene (10.40\%), 1,2,4-Trithiolane (48.95\%),17.alfa.,21á-28,30-Bisnorhopane (6.34\%), 1,3,5,7,9-Pentathiecane (13.47\%), 3Isopropylidene-tricyclo[4.3.1.1(2,5)]undecan-10-one (9.23\%), 4,25-Secoobscurinervan-4one, O-acetyl-22-ethyl-15,16-dimethoxy-, (22à)- (12.08\%),7-Diphenyl-1,6dioxopyridazino[4,5:2',3']pyrrolo[4',5'-d]pyridazine $\quad(23.66 \%), \quad$ Z,Z,Z-1,4,6,9-Nona Decatetraene (5.92\%), Unidentified compound (20.47\%), Galactonic phenylhydrazide (8.88\%), Cycloheptasiloxane, tetradecamethyl- (73.28\%), Cyclooctasiloxane, hexadecamethyl- (46.71\%), 2-Methyl-3,5-dinitrobenzyl alcohol, tert-butyldimethylsilyl ether $(8.26 \%)$, (5á)Pregnane-3,20á-diol, 14à,18à-[4-methyl-3-oxo-(1-oxa-4-azabutane- 
1,4-diyl)]-, diacetate (48.35\%), and 5-one, 9,9a-bis(acetyloxy)-1,1a,1b,2,4a,7a,7b,8,9,9adecahydro $(37.35 \%)$.

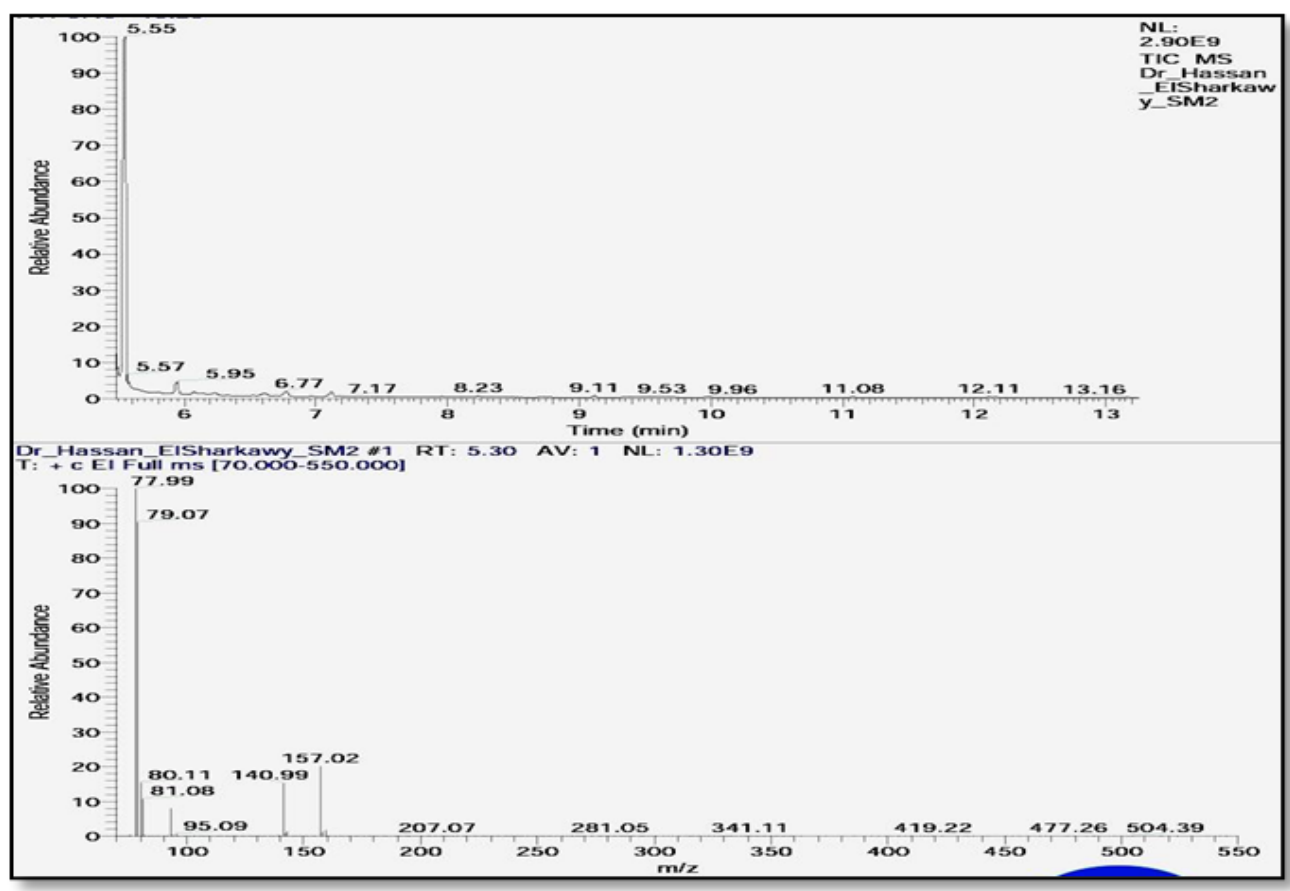

Fig. 3. GC-MS/MS chromatogram of D. setosum crude extract showing the retention time and molecular weights of the identified compounds.

\section{DISCUSSION}

Diadema setosum is a widespread species of sea urchins that have potential economic value. From the body part of sea urchins goand are commonly consumed. This organism can be used as a source of nutritious food because it contains amino acids, vitamin B complex, vitamin A, minerals, omega 3 and omega- 6 fatty acids. Recently, the shell of sea urchins has been proposed as a source for antibacterial agents (Hadinoto et al., 2017).

The obtained results of physicochemical analysis for seawater were generally in agreement with previous studies in the Red Sea recorded by Obuid Allah et al. (2005) and El-Metwally (2015). These parameters meet the optimal conditions for growth of urchins; Klinger et al. (1986) reported that sea urchins were more efficient at processing food at $23{ }^{\circ} \mathrm{C}$ comparing to $16^{\circ} \mathrm{C}$. Furthermore, Spirlet et al. (2000) showed that the temperature had a positive significant effect on their gonad production. In particular, sea urchins are known to be very sensitive to changes in water quality. Therefore, they frequently used as bioindicator for environmental degradation, such as water pollution (Rouane-Hacene et al., 2015). Previous studies showed that high ammonia and nitrite concentrations can affect the survival and growth of urchin gonads (Siikavuopio et al. 2004a). However, the distribution of nutrients during the present study was apparently independent of the water quality parameters. The levels of inorganic nutrient were generally low in all stations. In the study of Siikavuopio et al. (2004a, b) acute 
ammonium exposure cased mortality to Strongylocentrotus droebachiensis at $68 \mu \mathrm{g} / \mathrm{L}$, and their gonad growth was significantly impaired at a $\mathrm{NO}_{2}-\mathrm{N}$ concentration of $550 \mu \mathrm{g} / \mathrm{L}$.

Microbial populations in seawater and sediments may be as high as $10^{6}$ and $10^{9}$ per $\mathrm{ml}$, respectively (Austin, 1988). This means marine invertebrates are constantly exposed to high concentrations of bacteria, fungi, and viruses, many of which are pathogenic. Therefore, the survival of these organisms depends on the efficient antimicrobial mechanisms to protect themselves against numerous microbial infections.

In this study, the crude extract of sea urchin; D. setosum showed different specific inhibitory effect, with different bacterial strains (Gram positive or negative). Data conducted that the extract of the whole body was effective on several bacteria; E. coli ATCC 8739, S. aureus ATCC 25923, P. aeruginosa ATCC 9027, S. typhimurium, A. hydrophila, and $V$. damsel. As well as, it was effective on several fungi; $F$. solani, $A$. niger ATCC 16404, and $R$. solani

In such manner, many studies on microbial activity of sea urchin extracts have been reported with different results. For instance, the antibacterial activity has previously been described in a wide range of echinoderm species (Ridzwan et al., 1995). In most of the species studied, the whole body or body walls were tested for activity. Antimicrobial activity has also been reported in egg extracts of echinoid $P$. aracentrotus lividus (Stabili et al., 1996) and the asteroid Marthasterias glacialis (Stabili and Pagliara, 1994). In the latter study, the antibacterial compound was shown to be a lysozyme. The egg extracts of other marine invertebrates have also been shown to exhibit an antimicrobial activity. Antimicrobial activity was observed in both methanol and chloroform extracts of the ovary; however, the higher inhibition was exhibited by the methanol extracts. This suggested that the antimicrobial components might be present in the sea urchin ovary.

Moreover, Shankarlal et al. (2011) investigated antimicrobial properties of Salmacis virgulata methanolic extract. They found that all tested bacteria ( $S$. typhimurium, Proteus mirabilis, $P$. vulgaris, and $V$. cholera) were inhibited at $500 \mu \mathrm{g} / \mathrm{ml}$, as well as, all tested fungi (A. niger, A. flavus, and P. citrinum) except $C$. albicans were suppressed at $750 \mu \mathrm{g} / \mathrm{ml}$. Akerina et al. (2015) observed preliminary that the gonad extract showed higher antibacterial activity against both $E$. coli and $S$. aureus at $1.83 \mathrm{~mm}$ and $1.5 \mathrm{~mm}$, respectively. Marimuthu et al. (2015) also found that the sea urchin ovary extract has the higher zone of inhibition against a few bacteria compared to the conventional antibiotics such as streptomycin, ampicillin, cephalexin and gentamicin. For example, Ampicillin showed a very high antibacterial activity against $B$. subtilis and $S$. typhi. However, the methanol extract of sea urchin showed better zone of inhibition against Shigella flexneri, S. typhimurium, A. hydrophila, K. pneumoniae ATCC 13883, C. freundii, and $S$. aureus. Citrobacter freundii was not inhibited by ampicillin, cephalexin and gentamicin. Also, they found that the methanol extract of sea urchin ovary showed inhibition against these bacteria.

Recently, Salmaa et al. (2016) explored the antibacterial properties of ethyl acetate extract in the gonad of $D$. setosum on $S$. typhi and E. coli bacteria. Chemical screening of bioactive compounds in the gonad of D. setosum used ethyl acetate solvent, whereas the antibacterial sensitivity test was conducted by diluting the gonad extracts in 10\% DMSO. Furthermore, results showed that the gonad extracts contained flavonoids (orange to red color), steroids (greenish color), and saponin was marked in the form of foam for $15 \mathrm{~min}$. Meanwhile, the results of the culture test proved that ethyl acetate 
extract of the gonad of D. setosum inhibited the growth of E. coli and S. typhi at 80\% concentration classified into high inhibition response with the mean inhibition response was $21 \mathrm{~mm}$ for $E$. coli and mean inhibition response was $20 \mathrm{~mm}$ for $S$. typhi compared to the concentrations.

Hadinoto et al. (2017) determined the antibacterial activity of D. setosum shells extract. They conducted that the shell extract showed the antibacterial effect against Escherichia coli, Salmonella sp., and Bacillus cereus with a different inhibition zone of each tested one, as shown in the methanol extract $(1.84 \pm 0.05 \mathrm{~mm} ; 1.84 \pm 0.03 \mathrm{~mm}$ and $2.65 \pm 0.02 \mathrm{~mm})$, ethyl acetate extract $(14.18 \pm 0.02 \mathrm{~mm} ; 1.65 \pm 0.03 \mathrm{~mm}$ and $14.49 \pm 0.03$ $\mathrm{mm})$ and chloroform extract $(0.64 \pm 0.08 \mathrm{~mm}, 8.98 \pm 0.03 \mathrm{~mm}$, and $3.77 \pm 0.14 \mathrm{~mm})$.

Furthermore, the MICs of D. setosum crude extract during our investigation were in the range of $25-50 \mu \mathrm{g} / \mathrm{mL}$. The MIC test results obtained from the work of Shankarlal et al. (2011) exhibited that the MICs were $125 \mu \mathrm{g} / \mathrm{mL}$ against both $P$. mirabilis and $P$. vulgaris, $500 \mu \mathrm{g} / \mathrm{mL}$ towards $S$. typhimurium, $V$. cholera, and $P$. citrinum, and $750 \mu \mathrm{g} / \mathrm{mL}$ were able to inhibit $A$. niger and $C$. albicans as MIC. While higher values of MIC were recorded by Marimuthu et al. (2015). Their data showed that a MIC of $3.13 \mathrm{mg} / \mathrm{mL}$ was found to inhibit the growth of $S$. epidermidis ATCC 12228, and the Gram-negative bacteria had higher MIC values compared to the Gram-positive bacteria. This is because Gram-negative bacteria have a thick cell wall made up of lipids and polysaccharides thus increasing its resistance to antimicrobial agents. However, this study suggests that the ovary extract of $D$. setosum may be a potential source of antimicrobial agent for pathogenic microorganisms.

Generally, our study confirmed that the Gram-negative bacteria were more resistant than Gram positive. This may due to Gram negative bacteria have a largely impermeable thick cell wall (Exner et al., 2017). Also, the inhibition of D. setosum crude extract was lower than most commercial antibiotics may due to the bioactive substance in such crude is exposed to the dilution effect. So, it did not show high clearance zone around the tested microorganism. A study worked by Shankarlal et al. (2011) referred to that tetracycline $(100 \mu \mathrm{g} / \mathrm{mL})$ was very effective as a commercial antibiotic against all tested bacteria, like Streptomycin $(100 \mu \mathrm{g} / \mathrm{mL})$ that was potent against all tested fungi.

On the other hand, the bioactive compounds detected by GC/MS/MS in the present crude extract of $D$. setosum were organic and fatty acids and their derivatives, besides many other of organic alcohols, steroids, terpenoids, amino acids, esters and benzene derivatives. However, the antimicrobial activities of the most of these constituents have been identified and established and was attributed to the abundance of many compounds is characterized by antifungal and antibacterial activities (Ibrahim, 2012; Moustafa et al., 2013; Hussein et al., 2016; Ibrahim et al., 2018).

Focally, Kim et al. (2006) conducted that the acyclic thiosulfinates (1,2Dithiolane) possess antimicrobial, antiparasitic, antitumor and cysteine protease inhibitory activity while the natural 1,2-dithiolane-1-oxides are growth inhibitors. Also, Benkeblia et al. (2007) confirmed the effectiveness of the natural biologically active SMethyl methane thiosulphonate in the development of potent antifungal agents.

Shamsuddin et al. (2010) studied the antibacterial properties of ascertain compound in three respective sea urchin species such as D. setosum, D. savignyi, and Echinomatrix calamaris. They utilized three kinds of solvent for extraction method such as methanol, ethanol and a phosphate buffer solution for water-soluble substance 
extraction. Inner tissues and outer layers of each sea urchin species were subjected to be extracted. Negative results occurred for PBS extraction method in all extract samples. However, for inner-tissues extraction method, ethanol and methanol solvent exhibits positive results for inhibitory effects against several test strains of Gram-positive bacteria such as $S$. aureus, E. faecalis, and Gram-negative bacteria such as $S$. typhimurium, $P$. aeruginosa, and $E$. coli. Methanol solvent solely exhibits positive inhibitory effects against two Gram-positive bacteria, S. aureus and B. cereus for outer-layer extraction method of three sea urchin's species.

The results of Lazarević et al. (2011) showed that the derivative of 1,2,4trithiolane had antimicrobial properties. Among the microbes tested, the most susceptible strains were $P$. aeruginosa (minimal inhibitory/bactericidal concentration $=0.08 / 2.5$ $\mathrm{mg} / \mathrm{mL}$ and $A$. niger (minimal inhibitory/fungicidal concentration $=0.31 / 0.63 \mathrm{mg} / \mathrm{mL}$. Akerina et al. (2015) detected bioactive compounds from the three different solvents of gonads extracts were steroid, triterpenoid and saponin. Abd El-Karim (2016) detected the suppression effect of 2-Methyl-3,5-dinitrobenzyl alcohol and tert-butyldimethylsilyl ether. Hassan (2016) detected antibacterial activity of Cycloheptasiloxane, tetradecamethyl- and cyclooctasiloxane hexadecamethyl- in its hexane extract, against several pathogens.

Rahman et al. (2014) reported that many species of sea urchin male and female gonads are rich in valuable bioactive compounds viz. polyunsaturated fatty acids (PUFAs), especially eicosapentaenoic acid and docosahexaenoic acid, and $\beta$-carotene and some xanthophylls. Many fatty acids were recorded as antimicrobial agents (Wu et al., 2006; El Semary, 2012). They reported that some fatty acids have cytotoxic effects on other organisms. Wu et al. (2006) and Nielsen et al. (2010) attributed the cytotoxicity effects of fatty acids to their ability to increase the membrane permeability leading to membrane damage.

Many studies have shown that compounds of benzene derivatives not only exhibited antibacterial activities (Lee et al., 2009). It has previously been shown that some benzene inhibited b-ketoacyl-acyl carrier protein synthase III, a condensing enzyme that initiates fatty acid biosynthesis in most bacteria, leading to antimicrobial activity (Lee et al., 2009).

Terpenoids such as triterpenes, sesquiterpenes and diterpenes have been referred to as antibiotics, insecticides, anthelmintic and antiseptic in pharmaceutical industry (Parveen et al., 2010). The terpenoid fraction had weak antimicrobial activity against $P$. aeruginosa and E. coli (Mastelic et al., 2005) but cause high growth reductions of the medically important pathogen $S$. aureus and $C$. albicans, both were inhibited at a minimal concentration of $5 \mathrm{mg} \mathrm{mLG1} \mathrm{(Mastelic} \mathrm{et} \mathrm{al.,} \mathrm{2005).}$

Bilkova et al. (2015) studied the effect of different length chain glycosides on different pathogens and found that $S$. aureus and $C$. albicans were the most susceptible pathogens and showed potent activity at micromolar level, whereas E. coli was the least affected microorganism by the tested compounds. Many reports indicated that natural alkaloids (Hu et al., 2014) and natural saponins (Wang et al., 2012) are highly effective against a wide spectrum of pathogens. 


\section{CONCLUSION}

The current study has investigated the potential bioactive effects of crude extract of Diadema setosum. Our finding indicated strong antimicrobial effects of the extract; which emphasis the economic values of this species. This echinoderm is abundant in coastal area of the Red sea where the physicochemical parameters are suitable for their spread.. According to the obtained results, the crude extract of the whole body of $D$. setosum, collected from the Egyptian Red Sea, has excellent antimicrobial properties against a vast variety of pathogenic bacteria and fungi. Thus, this organism could be useful in industry of pharmaceutical products, since it possesses significant proactive capacities. Further studies have to be carried out on this sea urchin extract to separate and then elucidate the structure of the most effective bioactive substance(s). Finally, the unidentified compounded (with $\mathrm{C}_{36} \mathrm{H}_{46} \mathrm{O}_{8}$ and its Molecular weight equals 606), detected by the precise tool; GC-MS/MS, may be promising if it takes a chance within a future study.

\section{ACKNOWLEDGEMENT}

This research was partially supported by the National Institute of Oceanography and Fisheries. The authors would like to thank members of Microbiology Laboratory (NIOF, Alexandria) for providing us with pathogen strains.

\section{REFERENCES}

Abd El-Karim, M.S. (2016). Chemical Composition and Antimicrobial Activities of Cyanobacterial Mats from Hyper Saline Lakes, Northern Western Desert, Egypt. J. Appl. Sci., 16: 1-10.

Akerina, F.O.; Nurhayati, T. and Suwandy, R. (2015). Isolation and characterization of antibacterial compounds from sea urchin. JPHPI., 18(1): 61-73.

Amer, M.S. and Ibrahim, H.A.H. (2019). Chitosan from marine-derived Penicillum spinulosum $\mathrm{MH} 2$ cell wall with special emphasis on its antimicrobial and antifouling properties. Egy. J. Aqua. Res., 45: 359-365.

Andrews, J.M. (2001). Determination of minimum inhibitory concentrations. J. Antimicrob. Chemother. 48:5-16.

Atlas, R.M. (1997). Handbook of media for environmental microbiology (p. 265, 412). Boca Raton, FL: CR Press.

Audouin, V. (1826). Explication sommaire des planches de Crustacés de l'Égypte et de la Syrie, publiées par Jules-César Savigny, Membre de l'Institut; offrant un exposé des caractères naturels des genres, avec la distinction des espèces. Histoire Naturelle, 1(4): 77-98.

Austin, B. (1988). Marine Microbiology. Cambridge University Press, Cambridge.

Benkeblia, N. and Lanzotti, V. (2007). Allium thiosulfinates: Chemistry, biological properties and their potential utilization in food preservation. Food-Global Science Books. 1(2): 193-201.

Bilkova, A.; Paulovicova, E.; Paulovicova, L. and Polakova, M. (2015). Antimicrobial activity of mannose-derived glycosides. Chem. Monthly, 146: 1707-1714. 
Britton, G.; Liaaen-Jensen, S. and Pfander, H. (2004). Carotenoids handbook. Boston, USA: Birkhauser Verlag.

Casas, S.M.; Comesana, P.; Cao, A. and Villalba, A. (2011). Comparison of antibacterial activity in the hemolymph of marine bivalves from Galicia (NW Spain). J. Invertebr. Pathol., 106: 343-345.

Dincer, T. and Cakli, S. (2007). Chemical composition and biometrical measurements of the Turkish Sea urchin (Paracentrotus lividus, Lamarck, 1816). Crit. Rev. Food Sci. Nutr., 47: 21-26.

El Semary, N.A. (2012). The antimicrobial profile of extracts of a Phormidium-like cyanobacterium changes with phosphate levels. World J. Microbiol. Biotechnol., 28: 585-593.

Elmasry, E.; Omar, H.; Razek, F.A. and El-Magd, M. (2013). Preliminary studies on habitat and diversity of some sea urchin species (Echinodermata: Echinoidea) on the southern Levantine basin of Egypt. Egy. J. Aqua. Res., 39(4): 303-311.

El-Metwally, M.E.A. (2015). Monitoring of heavy metals pollution in the Egyptian Red Sea coast and response of marine organisms, Ph.D. Thesis, Mansoura Univ., p. 275

Exner, M.; Bhattacharya, S.; Christiansen, B.; Gebel, J.; Goroncy-Bermes, P.; Hartemann, P.; Heeg, P.; Ilschner, C.; Kramer, A.; Larson, E.; Merkens, W.; Mielke, M.; Oltmanns, P.; Ross, B.; Rotter, M.; Schmithausen, R.M.; Sonntag, H.G. and Trautmann, M. (2017). Antibiotic resistance: What is so special about multidrug-resistant Gram-negative bacteria? GMS Hyg. Inf. Con., 12: Doc05.

Grasshoff, K.; Kremling, K. and Ehrhardt, M. (Eds.) (1999). Methods of Seawater Analysis. $3^{\text {rd }}$ Edition. Weinheim: Wiley-VCH. 632 pages.

Guinea, J; Peláez, T.; Alcalá, L. and Bouza, E. (2005). Evaluation of Czapeck agar and Sabouraud dextrose agar for the culture of airborne Aspergillus conidia. Diagn. Microbiol. Infect Dis., 53(4): 333-334.

Hadinoto, S.; Sukaryono, I.D. and Siahay, Y. (2017). Nutrition content of sea urchin (Diadema setosum) gonad and antibacteria activities of its shell extracts. JPB Kelautan dan Perikanan, 12(1): 71-78.

Hassan, S.W.M. (2016). Antibacterial, anticoagulant and anti-inflammatory activities of marine Bacillus cereus S1. J. Pure Appl. Microbiol., 10(4): 2593-2606.

Hu, J.; Shi, X.; Chen, J.; Mao, X.; Zhu, L.; Yu, L. and Shi, J. (2014). Alkaloids from Toddalia asiatica and their cytotoxic, antimicrobial and antifungal activities. Food Chem., 148: 437-444.

Hussein, H.M.; Hameed, I.H. and Ibraheem, O.R. (2016). Antimicrobial activity and spectral chemical analysis of methanolic leaves extract of Adiantum CapillusVeneris using GC-MS and FTIR spectroscopy. Int. J. Pharmacog. Phytochem. Res., 8(3): 369-385.

Ibrahim, H.A.H. (2012). Antibacterial carotenoids of three Holithoria species in Hurghada, Egypt. Egy. J. Aqua. Res. 38: 185-194.

Ibrahim, H.A.H.; Ahmed, H.O.; Abd El Razek, F.A. and Elmasry, E. (2018). Proteolysis and heat-sensitive antibacterial agents from several levantine sponge species. Int. J. Adv. Res., 6(2): 14-27. 
Ibrahim, H.A.H.; Elabiary, D.E. and Hamed M.M. (2020a). Antimicrobial activity of some Egyptian marine invertebrates, Red Sea. Egyptian J. Aqua. Biol. Fish., 24(4): 321-340.

Ibrahim, H.A.H.; Elshaer, M.M.; Elatriby, D.E. and Ahmed, H.O. (2020b). Antimicrobial activity of the sea star (Astropectens pinulosus) collected from the Egyptian Mediterranean Sea, Alexandria. Egyptian J. Aqua. Biol. Fish., 24(2): 507-523.

Ibrahim, H.A.H.; Amer, M.S.; Ahmed, H.O. and Hassan, N.A. (2020c). Antimicrobial activity of the sea hare (Aplysia fasciata) collected from the Egyptian Mediterranean Sea, Alexandria. Egyptian J. Aqua. Biol. Fish., 24(4): 233-248.

Khan, Z.A.; Siddiqui, M.F. and Park, S. (2019). Current and emerging methods of antibiotic susceptibility testing. Diagnostics (Basel)., 9(2): 49-55.

Kim, S.; Kubec, R. and Musah, R.A. (2006). Antibacterial and antifungal activity of sulfur-containing compounds from Petiveria alliacea. J. Ethnopharmacol., 104: 188-192.

Klinger, T.S.; Hsieh, H.L.; Pangallo, R.A.; Chen, C.P. and Lawrence, J.M. (1986). The effect of temperature on feeding, digestion and absorption of Lytechinus variegates (Lamarck) (Echinodermata: Echinoidea). Physiol. Zool., 59: 332-336.

Lawrence, J.M. (2010). Edible sea urchins: Biology and ecology. Boston, USA: Elsevier.

Lazarević, J.S.; Ethorđević, A.S.; Zlatković, B.K.; Radulović, N.S. and Palić, R.M. (2011). Chemical composition and antioxidant and antimicrobial activities of essential oil of Allium sphaerocephalon L. subsp. sphaerocephalon (Liliaceae) inflorescences. J. Sci. Food Agric., 91(2): 322-329.

Lee, J.Y.; Jeong, K.W.; Lee, J.U.; Kang, D.I. and Kim, Y. (2009). Novel E. coli \$ketoacyl-acyl carrier protein synthase III inhibitors as targeted antibiotics. Bioorg. Med. Chem., 17: 1506-1513.

Lessios, H.A.; Kessing, B.D. and Pearse, J.S. (2001). Population structure and speciation in tropical seas: global phylogeography of the sea urchin diadema. Evol., 55: 955-975.

Manchenko, G.P. and Yakovlev, S.N. (2001). Genetic divergence between three sea urchin species of the genus Strongylocentrotus from the Sea of Japan. Biochem. System. Ecol., 29(1): 31-44.

Marimuthu, K.P.; Gunaselvam, P.; Rahman, A.; Xavier, R.; Arockiaraj, J.; Subramanian, S.; Yousoff, F.M. and Arshad, A. (2015). Eur. Rev. Med. Pharmacol. Sci., 19: 1895-1899.

Mastelic, J.; Politeo, O.; Jerkovic, I. and Radosevic, N. (2005). Composition and antimicrobial activity of Helichrysum italicum essential oil and its terpene and terpenoid fractions. Chem. Nat. Compd., 41: 35-40.

Moustafa, M.F.M.; Alamri, S.A.; Taha, T.H. and Alrumman, S.A. (2013). In vitro antifungal activity of Argemone ochroleuca sweet latex against some pathogenic fungi. Afr. J. Biotechnol., 12(10): 1132-1137.

Nielsen, S.B.; Wilhelm, K.; Vad, B.; Schleucher, J.; Morozova-Roche, L.A. and Otzen, D. (2010). The interaction of equine lysozyme: Oleic acid complexes with lipid membranes suggests a cargo off-loading mechanism. J. Mol. Biol., 398: 351361. 
ObuidAllah, A.H.; Abadlla, A.; Abu-Eldahab, H.M.; Abdul-Rahman, N.M. and Mahdy, A.A. (2005). Impact of heavy metal concentration on seasonal abundance of planktonic copepods inhabiting mangrove area in Safaga, Red Sea, Egypt. Egy. J. Exp. Biol. (Zool.), 1: 123-130.

Parveen, M.; Ghalib, R.M.; Khanam, Z.; Mehdi, S.H. and Ali, M. (2010). A novel antimicrobial agent from the leaves of Peltophorum vogelianum (Benth.). Nat. Prod. Res., 24: 1268-1273.

Pulz, O. and Gross, W. (2004). Valuable products from biotechnology of microalgae. Appl. Microbiol. Biotech., 65: 635-648.

Rahman, M.A.; Amin, S.M.N.; Yusoff, F.M.; Kuppan, P. and Shamsudin, M.N. (2012). Length weight relationships and fecundity estimates of long-spined sea urchin, Diadema setosum, fron Pulau Pangkor, Peninsular Malaysia. Aquat Ecosys Health Manage; 15: 311-315.

Rahman, M.A.; Arshad, A.Md. and Yusoff, F. (2014). Sea Urchins (Echinodermata: Echinoidea): Their Biology, Culture and Bioactive Compounds. Int. Conf. Agricultural, Ecological and Medical Sciences (AEMS-2014) July 3-4 London (UK). Doi.org/10.15242/ IICBE.C714075.

Ridzwan, B.H.; Kaswandi, M.A.; Azman, Y. and Fuad M. (1995). Screening for antibacterial agents in three species of sea cucumbers from coastal areas of Sabah. Gen. Pharmacol., 26: 1539-1543.

Rouane-Hacene, O.; Boutiba, Z.; Belhaouari, B.; Guibbolini-Sabatier, M.E.; Francour, P. and Risso-de Faverney, C. (2015). Seasonal assessment of biological indices, bioaccumulation and bioavailability of heavy metals in mussels Mytilus galloprovincialis from Algerian west coast, applied to environmental monitoring. Oceanol., 57: 362-374.

Salmaa, W.O.; Esoc, A.A.; Kusnand, A.; Fristiohadye, A.; Nurdinf, K.D.S.; Bastamang, M.R.; Abdilahh, M.N. and Mudjahidahi, N.H. (2016). Gonad extracts of Diadema setosum as potential antibacterial agent derived from Wakatobi District Sea Waters Southeast Sulawesi Province-Indonesia. Int. J. Sci.: Basic Appl. Res., 49(1): 125-132.

Shaaban, M.T.; Ibrahim, H.A.H. and Hanafi, A.A.M. (2020). Antibiotic-resistant bacteria isolated from selected urine and stool human specimens. Biosci. Res., 17(1): 351-365.

Shamsuddin, A.A.; Lukman Hakim, M.D.; Kumari, G.M. and Noraznawati, I. (2010). Anti-bacterial activity of three species of sea urchin extracts from Pulau Bidong, Terengganu. J. Sustain. Sci. Manag., 5(1):116-124.

Shankarlal, S.; Prabu, K. and Natarajan, E. (2011). Antimicrobial and antioxidant activity of purple sea urchin shell (Salmacis virgulata L. Agassiz and Desor 1846). Am.-Eur. J. Sci. Res., 6(3): 178-181.

Sidiqi, F.M.; Pringgenies, D.1. and Setyati, W.A.1. (2019). Antibacterial activity of gonad Methanol extract of the sea urchin Diadema setosum against methicillinresistant Staphylococcus aureus and Escherichia coli. $4^{\text {th }}$ International Conference on Tropical and Coastal Region Eco Development IOP Conf. Series: Earth and Environmental Science 246. 
Siikavuopio, S.I.; Christiansen, J.C.; Dale, T. and Nevermo, I. (2004b). Effects of chronic nitrite exposure on gonad growth and survival in green sea urchin, Strongylocentrotus droebachiensis. Aquacul., 242: 357-363

Siikavuopio, S.I.; Dale, T.; Foss, A. and Mortensen, A. (2004a). Effects of chronic ammonia exposure on gonad growth and survival in greensea urchin, Strongylocentrotus droebachiensis. Aquaculture 242:313-320.

Spirlet, C.; Grosjean, P. and Jangoux, M. (2000). Optimization of gonad growth by manipulation of temperature and photoperiod in cultivated sea urchins, Paracentrotus lividus (Lamarck) (Echinodermata). Aquacul., 185: 85-99.

Stabili, L. and Pagliara, P. (1994). Antibacterial protection in Marthasterias glacialis eggs- characterization of lysozyme-like activity. Comp. Biochem. Physiol., B(109): 709-713.

Stabili, L.; Lassagues, M. and Pastore, M. (1996). Preliminary study on the antibacterial capabilities of eggs of Paracentrotus lividus (Echinodermata: Echinodea). J. Invertebr. Pathol; 67: 180-182.

Wang, J.; Liu, K.; Gong, W.Z.; Wang, Q. and Xu, D.T. et al., (2012). Anticancer, antioxidant and antimicrobial activities of anemone (Anemone cathayensis). Food Sci. Biotechnol., 21: 551-557.

Wu, J.T.; Chiang, Y.R.; Huang, W.Y. and Jane, W.Y. (2006). Cytotoxic effects of free fatty acids on phytoplankton algae and cyanobacteria. Aqua. Toxicol., 80: 338-345.

Zeina, A.F.; Darweesh, K.F. and Hellal, A.M. (2016). Sea urchins (Echinoidea: Echinodermata) from Gulf of Aqaba, Red Sea, Egypt. Int. J. Develop., 5(1): 2745. 


\title{
$\underline{\text { Arabic summary }}$
}

\author{
العوامل المضادة للميكروبات من قنفة البحر (Diadema setosum) المجموع من البحر الأحمر، مصر \\ وليد محمد محمود السبيد'، مصطفى محمد الثاعر"، حسن عبد الله حسن إبراهيخ"، محمد علي المتولي؛ \\ "قسم الميكروبيولوجيا البحرية، المعهل القومي لطوم البحار والمصايد، البحر الأحمر - مصر.

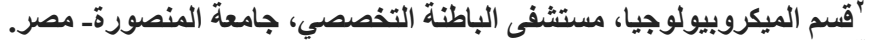

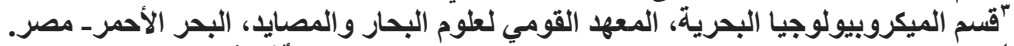

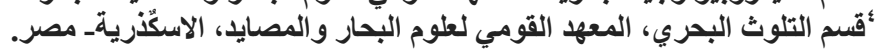

في هذه الدراسة، تم جمع نوع من قنفذ البحر من سواحل البحر الأحمر، مصر، لكي تدرس فئل الكيه الأنشطة

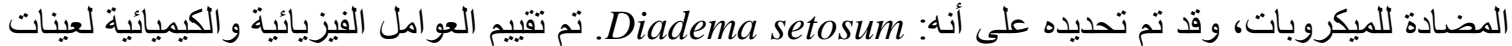

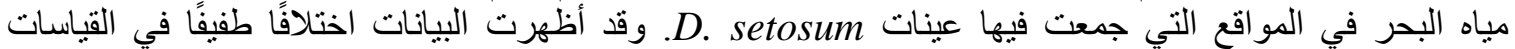

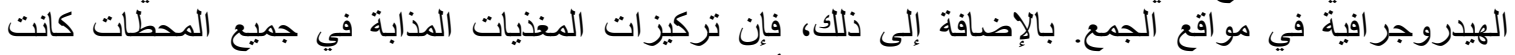

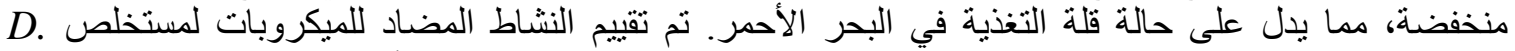

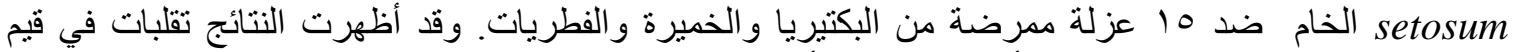

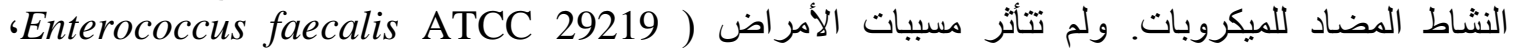
‘Klebsiella pneumoniae ATCC 13883 ،Staphylococcus epidermidis ATCC 12228 (Vibrio fluvialis ،Bacillus subtilis ATCC 6633

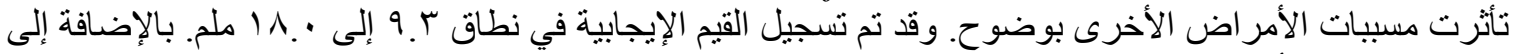

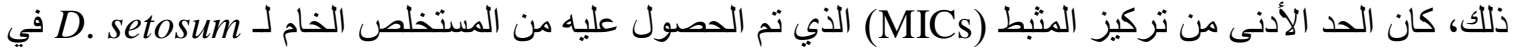

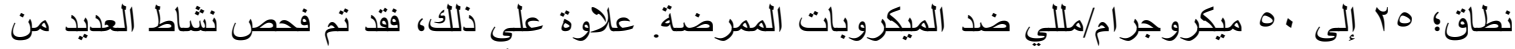

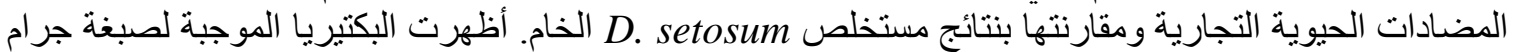

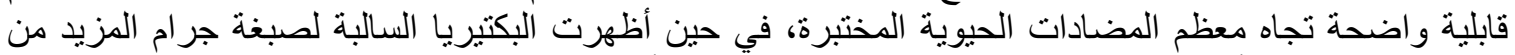

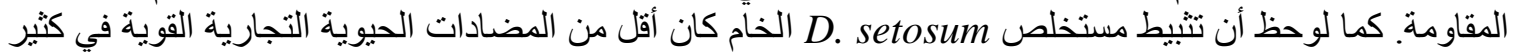

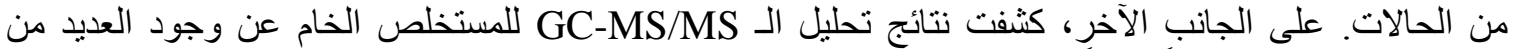

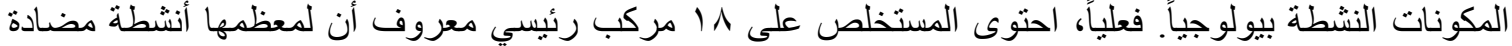

